\title{
Hypertension and tachycardia during adrenal manipulation
}

\begin{abstract}
The purpose of this report is to draw attention to haemodynamic changes during intraoperative adrenal gland manipulation. Severe hypertension, ventricular tachycardia and subendocardial ischaemia occurred during the manipulation of adrenal gland in a patient who underwent live related donor nephrectomy. The patient responded well to intravenous lidocaine. Plasma norepinephrine concentration was elevated at the time of event. Further investigations after surgery excluded the possibility of phaeochromocytoma. In two years follow-up patient remains well. Suspicion for the cause of the event remains the excessive release of catecholamines with manipulation of a normal adrenal gland. The presence of halothane might have contributed to the arrythmia.
\end{abstract}

Cette observation vise à attirer l'attention sur les répercussions hémodynamiques provoquées par la manipulation peropératoire de la glande surrénale. De l'hypertension grave, de la tachycardie ventriculaire et de l'sschémie sous-endocardique surviennent pendant la manipulation de la surrénale chez un patient soumis une néphrectomie pour don d'organe. Le patient réagit favorablement à la lidocaïne intraveineuse. Au moment de l'incident, la concentration de norépinéphrine plasmatique est élevée. L'investigation postchirurgicale exclut la possibilité d'un phéochromocytome. Après deux ans, le patient est toujours en bonne santé. L'explication de cette complication la plus plausible demeure la libération excessive de catécholamine par manipulation d'une glande surrénale normale. Lhalothane pourrait avoir exagéré l'arythmie.

\section{Key words}

COMPLICATIONS: arrhythmia, hypertension; HORMONES: adrenal;

SURGERY: phaeochromocytoma.

From the Department of Anaesthesiology \& Critical Care Medicine, SGPGIMS, Raibareli Road, Lucknow, India,

Post Code 226014.

Address correspondence to: Dr. Prabhat Tewari, Department of Anaesthesiology \& Critical Care Medicine, Sanjay Gandhi Post Graduate Institute of Medical Sciences, Raibareli Road, Lucknow (U.P.), India 226014.

Accepted for publication 1st January, 1995.
Living related donor nephrectomy is usually a safe and uneventful procedure. A case is described where handling of a normal adrenal gland during general anaesthesia resulted in severe hypertension, ventricular tachycardia and subendocardial ischaemia in a patient who was undergoing graft nephrectomy.

\section{Case report}

A 50-yr-old $71 \mathrm{~kg}$ man was admitted for living related donor nephrectomy. Preoperative assessment was normal; there were no symptoms of disease and the routine investigations were haemoglobin $13.5 \mathrm{~g} \cdot \mathrm{dl}^{-1}$, total leukocyte count $6.7 \times 10^{-3} \cdot \mathrm{dl}^{-1}$, haematocrit $40 \%$, blood urea $38 \mathrm{~g} \cdot \mathrm{dl}^{-1}$, Serum creatine $0.2 \mathrm{mg} \cdot \mathrm{dl}^{-1}$, serum sodium and potassium 138 and $3.8 \mathrm{meq} \cdot \mathrm{L}^{-1}$ respectively, blood glucose (random $124 \mathrm{~g} \cdot \mathrm{dl}^{-1}$ ), blood pressure $136 /$ $88 \mathrm{mmHg}$ and pulse rate $72 \mathrm{bpm}$. No abnormality was detected on plain chest $x$-ray as with 12 lead ECG.

Premedication with pentazocine, $30 \mathrm{mg} \mathrm{im}$, and promethazine $25 \mathrm{mg} \mathrm{im}$, was given one hour before surgery. General anaesthesia was induced with thiopentone, 350 $\mathrm{mg}$, and muscle relaxation was produced with pancuronium, $0.1 \mathrm{mg} \cdot \mathrm{kg}^{-1}$. Anaesthesia was maintained with nitrous oxide and oxygen (60:40), pentazocine, $30 \mathrm{mg}$ $i v$, and halothane, $0.5 \%$ inspired. During the procedure ECG, CVP, BP (invasive), Core temperature and $\mathrm{PETCO}_{2}$ were monitored (Hewlett Packard \# 78354a). Oxygen saturation (PULSEOX7, Minolta), muscle relaxation (Myotest DBS, Biometer, Denmark) and urine output were also monitored. The patient was placed in the lateral position with the left side up and with the kidney bridge at its maximum height. During surgery a mannitol infusion, $1 \mathrm{~g} \cdot \mathrm{kg}^{-1}$ was started. Exposure of the upper pole of kidney was difficult and the adrenal gland was handled vigorously. The blood pressure, which until now had been stable at $130 / 80$, suddenly increased to $260 / 140 \mathrm{mmHg}$ and sinus rhythm converted into ventricular tachycardia. Also, the CVP increased by $4 \mathrm{mmHg}$, PETCO $_{2}$ decreased by $8 \mathrm{mmHg}$ and $\mathrm{PaCO}_{2}$ decreased by $6 \mathrm{mmHg}$. Halothane was withdrawn and lidocaine, $2 \mathrm{mg} \cdot \mathrm{kg}^{-1} \mathrm{iv}$, was given which restored sinus rhythm at $80 \mathrm{bpm}$. However, the BP was $200 / 100 \mathrm{mmHg}$ with ECG S-T segment flattening and the " $\mathrm{J}$ " point was $3 \mathrm{~mm}$ below the baseline indicating severe subendocardial ischaemia. An arterial 
blood sample was collected and sent for catecholamine assay. A nitroglycerin infusion was started at the rate of $0.5 \mathrm{mg} \cdot \mathrm{kg}^{-1} \cdot \mathrm{min}^{-1}$. The BP was $120 / 90 \mathrm{mmHg}$ within three minutes but it took $30 \mathrm{~min}$ for the ECG to return to normal. Then, surgery and anaesthesia were continued without incident. At the end of the operation the patient was turned supine and atropine, $0.6 \mathrm{mg}$, neostigmine $2.5 \mathrm{mg}$, mixture was given to reverse the residual neuromuscular blockade. The patient became alert and obeyed commands and the heart rate and blood pressure were $70 \mathrm{bpm}$ and $130 / 84 \mathrm{mmHg}$ respectively. The postoperative recovery was uneventful.

A blood sample collected during the acute event showed elevated concentration of norepinephrine (6.5 $\left.\mathrm{nmol} \cdot \mathrm{L}^{-1}\right)$ and slight increase in epinephrine concentration $\left(300 \mathrm{pmol} \cdot \mathrm{L}^{-1}\right)$. Magnetic resonance imaging, whole body CT scanning and 131 I-metaiodobenzylguanidine scintigraphy after surgery showed no signs of phaeochromocytoma. Twelve and $24 \mathrm{hr}$ postoperative plasma samples showed normal catecholamine concentrations. The 24 and $48 \mathrm{hr}$ urine samples showed normal basal levels of total unconjugated catecholamines, vinyll mandelic acid and total metanephrine. After two years the patient remains well.

\section{Discussion}

Haemodynamic changes and arrhythmias in the intraoperative period have kept anaesthetists working towards safer techniques and better anaesthetic agents. In spite of improved preoperative vigilance and intensive intraoperative monitoring unusual episodes of hypertension along with life-threatening arrhythmias can occur during surgery.'

The patient described above had such an episode when the adrenal gland was manipulated during the course of surgery. High catecholamine concentrations during the episode explained the hypertension and reflex bradycardia. The rise in central venous pressure was due to a shift of fluid to the central compartment due to severe peripheral venous vasoconstriction. Similarly decreases in $\mathrm{PaCO}_{2}$ and $\mathrm{PETCO}_{2}$ may reflect reduced oxygen utilization. Ventricular tachycardia could have been due either to subendocardial ischaemia following sudden hypertension resulting in dilatation of left ventricle or to myocardial sensitization by halothane and its interaction with high concentrations of catecholamines. ${ }^{2}$

As there are no reports of the normal adrenal gland releasing sufficient catecholamines on surgical handling to lead to ventricular arrhythmias, the suspicion of phaeochromocytoma was considered. ${ }^{3,4}$ Phaeochromocytomas secrete both norepinephrine and epinephrine. ${ }^{5}$ This episode was a singular event in an otherwise healthy patient. Although the normal adrenal medulla usually stores only epinephrine, on stimulation it may also release norepinephrine. ${ }^{6,7}$ The other condition which may give rise to a similar clinical picture is adrenal medullary hyperplasia, a predominantly epinephrine secreting condition diagnosed by MIBG scanning. ${ }^{8,9}$ However, the normal postoperative investigations and follow-up of this patient do not support the presence of either.

Halothane is more arrythmogenic than other inhalational anaesthetic agents. ${ }^{10}$ It especially acts on the myocardium sensitized by catecholamines. ${ }^{11}$ Although it may seem prudent to avoid halothane in such surgery two series $^{3,12}$ started to demonstrate no abnormal intraoperative behaviour during surgery for removal of phaeochromocytoma with halothane. The use of isoflurane or enflurane seems to be less arrhythmogenic than halothane and preferred. ${ }^{10}$ None of these agents were available to us when this episode occurred. Potent opioid analgesics with nitrous oxide can also be used in such patients so that inhalational agents can be avoided.

A sudden decrease in $\mathrm{PETCO}_{2}$ is also seen with air embolism but the surgical wound was nearly dry at the time of episode and there was no obvious access of air to circulation. A simultaneous decrease in $\mathrm{PaCO}_{2}$ without hypotension is not typical of massive air embolism.

We conclude that surgery around the adrenal gland calls for gentle handling of the gland and careful selection of the anaesthetic technique. This may include avoidance of halothane, use of other inhalational anaesthetic agents or of opioids and total intravenous anaesthesia. Lifethreatening arrhythmias are difficult to manage especially when the patient is placed in an unusual posture.

\section{References}

1 Forrest JB, Rehder $K$, Cahalan $M K$, Goldsmith $C H$. Multicenter study of general anaesthesia III. Predictors of severe perioperative adverse outcomes. Anesthesiology, 1992; 76: 3-15.

2 Katz RL, Katz GJ. Surgical infiltration of pressor drugs and their interaction with volatile anaesthetics. BMJ 1966; 38: 712-6.

3 Boutros AR, Bravo EL, Zanettin G, Straffon RA. Perioperative management of 63 patients with pheochromocytoma. Cleve Clin J Med, 1990; 57: 613-7.

4 Rorie $D K$. Unsuspected pheochromocytoma in a surgical patient. Anesthesiology 1975; 43: 363-4.

5 Aronoff SL, Passamani E, Borowsky BA, Weiss AN, Roberts $R, C r y e r P E$. Norepinephrine and epinephrine secretion from a clinically epinephrine-secreting pheochromocytoma. Am J Med 1980; 69: 321-3.

6 Landsberg L, Greff L, Gunn S, Young JB. Adrenergic mechanisms in the metabolic adaptation to fasting and feeding: effects of phlorizin on diet induced changes in sym- 
pathoadrenal activity in the rat. Metabolism 1980; 29 : 1128-37.

7 Rappaport EB, Young JB, Landsberg $L$. Effects of 2 deoxy-D-glucose on the cardiac sympathetic nerves and the adrenal medulla in the rat: further evidence for a dissociation of sympathetic nervous system and adrenal medullary responses. Endocrinology 1982; 110: 650-6.

8 Streeten DHP, Anderson GH Jr, Lebowitz M, Speller PJ. Primary hyperepinephrinemia in patients without pheochromocytoma. Arch Intern Med 1990; 150: 1528-33.

9 Dralle H, Schröder S, Gratz KF, Grote R, Padberg B, Hesch $R D$. Sporadic unilateral adrenomedullary hyperplasia with hypertension cured by adrenalectomy. World $\mathrm{J}$ Surg 1990; 14: 308-16.

10 Johnston RR, Eger EI II, Wilson C. A comparative interaction of epinephrine with enflurane, isoflurane, and halothane in man. Anesth Analg 1976; 55: 709-13.

11 Sumikawa K, Ishizaka N, Suzaki M. Arrhythmogenic plasma levels of epinephrine during halothane, enflurane, and pentobarbital anesthesia in the dog. Anesthesiology 1983; 58: 322-5.

12 Desmonts JM, le Houelleur J, Remond P, Duvaldestin P. Anaesthetic management of patients with phaeochromocytoma. A review of 102 cases. Br J Anaesth 1977; 49: 991-3. 